\begin{tabular}{|c|c|c|c|c|}
\hline $\begin{array}{c}\text { Focus: } \\
\text { Jurnal Pekerjaan Sosial }\end{array}$ & ISSN: 2620-3367 & Vol. 1 No: 3 & Hal: $220-233$ & Desember 2018 \\
\hline
\end{tabular}

\title{
I mplementasi Teori Maslow dan Peran Ganda Pekerja Wanita K3L Universitas Padajajaran
}

\author{
Philia Anindita Ginting \\ Philia17001@mail.unpad.ac
}

\begin{abstract}
Abstrak
Saat ini, fenomena wanita bekerja tidak lagi menjadi hal yang asing. Wanita dituntut untuk berperan lebih dari satu karena berbagai faktor, salah satunya persoalan ekonomi. Seperti halnya petugas wanita K3L Universitas Padjajaran. Kondisi perekonomian menyebabkan petugas wanita K3L dihadapkan kepada dua tuntutan peran yaitu sebagai seorang istri atau ibu rumahtangga dan pencari nafkah demi membantu memenuhi kebutuhan pokok keluarga. Walaupun kondisi kehidupannya tidak banyak berubah sejak menjadi petugas K3L namun kegiatan ini tidak ditinggalkan. Keterbatasan pendidikan dan keterampilan serta desakan dalam pemenuhan kebutuhan hidup merupakan salah satu faktor K3L bertahan untuk tetap bekerja. Artikel ini akan mengkaji mengenai peran ganda perempuan khsusunya pekerja K3L serta motivasi kerja yang dilihat dari Teori Hierarki Kebutuhan Abraham Maslow.
\end{abstract}

Kata kunci : Petugas Keindahan Kebersihan dan Kenyamanan Lingkungan (K3L), Peran Ganda Wanita, Teori Hierarki Kebutuhan Maslow

\section{Abstract}

Currently, the phenomenon of working women is no longer a strange thing. Women are required to have more than one role due to various factors, one of them is economic problem. This is what happened with K3L Padjajaran University female officers. The economic condition causes K3L female officers to be confronted with two roles as a housewife and breadwinner in order to supply the basic needs of her family. Although the condition of their life has not changed much since becoming a K3L officers but this activity is not abandoned. The education and skill limitationTheir limitations of life needs are one of the reason why they stayed. Furthermore, this article will examine the dual roles of women especially K3L workers and the work motivation seen from Abraham maslow's Hierarchy of Needs Theory

Keywords : officer of Hygiene ,Beauty, and Environmental Confort (K3L), Women Double Roles, Maslow's Hierarchy of Needs Theory 


\begin{tabular}{|c|c|c|c|c|}
\hline $\begin{array}{c}\text { Focus: } \\
\text { Jurnal Pekerjaan Sosial }\end{array}$ & ISSN: 2620-3367 & Vol. 1 No: 3 & Hal: 220 - 233 & Desember 2018 \\
\hline
\end{tabular}

\section{Pendahuluan}

Bekerja merupakan salah satu aktivitas dominan pada manusia. Ada bermacam-macam alasan dan tujuan manusia bekerja. Alasan paling mendasar adalah untuk mencari nafkah agar dapat memenuhi kebutuhan pokok seperti sandang, pangan, dan papan. Dalam upaya memenuhi kebutuhan tersebut dibutuhkan biaya dan manusia perlu bekerja untuk dapat membayar harga dari pemenuhan kebutuhan itu. Di masa ini, berbicara tentang peran maupun pekerjaan tidak lepas dari persoalan gender.

Sejak dulu , tugas-tugas domestik seperti memasak, mengasuh dan mendidik anak , memebersihkan dan melakukan pekerjaan rumah , dan lain-lain adalah tugas perempuan, bahkan sudah dianggap kodratnya. Sebaliknya, laki-laki menanggung peran dalam mencari nafkah , menjadi kepala rumah tangga maupun tugas-tugas dalam ruang publik lainnya. Namun faktanya saat ini di Indonesia banyak wanita yang memiliki peran ganda. Pada tahun 2002 tercatat angkatan kerja wanita di pulau Jawa sebesar 20.717.000 sedangkan di seluruh Indonesia 34.399.000. Data tersebut menepis anggapan bila perempuan tidak mempunyai peran dalam pereknonomian keluarga. Ananta ( 1990:160 ) mengemukakan tingginya partisipasi angkatan kerja wanita dalam kegiatan ekonomi dilandasi oleh beberapa hal, diantaranya : (1) Adanya perubahan pandangan dan sikap dalam masyarakat tentang sama pentingnya pendidikan bagi kaum pria dan wanita serta semakin disadari perlunya kaum wanita ikut berpartisipasi dalam pembangunan, (2) Adanya kemauan wanita untuk mandiri dalam bidang ekonomii yaitu berusaya membiayai kebutuhan hidupnya ( dan juga kebutuhan hidup orang-orang yang menjadi tangguannya ) dengan penghasilan sendiri, (3) Adanya kebutuhan untuk menambah penghasilan keluarga, (4) Makin luasnya kesempatan kerja yang bisa menyerap tenaga kerja wanita, misalnya tumbuhnya industri kerajinan tangan dan industry ringan lainnya.

Perlu diketahui meningkatnya keterlibatan wanita dalam kegiatan ekonomi dipengaruhi oleh beberapa faktor, seperti faktor sosial, ekonomi, maupun demografi. Faktor demografi yang dimaksud tersebut adalah tingkat pendidikan, jenis kelamin , umur, dan status perkawinan. Artikel ini secara khusus akan membahas tentang angakatan kerja wanita petugas kebersihan, keindahan , dan kenyamanan (K3L) Universitas Padjadjaran. Berdasarkan hasil observasi yang telah dilakukan kepada petugas Kebersihan, Keindahan dan Kenyamanan (K3L) Universitas Padajajaran diperoleh data sebagai berikut:

Dari data yang telah diolah menunjukkan bahwa dari 24 K3L di Zona 3 Universitas Padjajaran , $75 \%$ nya berjenis kelamin wanita, hanya seperempatnya berjenis kelamin laki-laki. Maka dari sini diketahui bahwa jumlah K3L Universitas Padjajaran pada Zona 3 lebih banyak yang berjenis

\begin{tabular}{|l|l|l|l|}
\hline No & Jenis Kelamin & $f$ & $\%$ \\
\hline 1 & Laki-Laki & 6 & $25 \%$ \\
\hline 2 & Wanita & 18 & $75 \%$ \\
\hline
\end{tabular}

kelamin wanita.

Tabel 1. Persentase Jumlah Pekerja K3L Zona 3 berdasarkan jenis kelamin

Selanjutnya tabel 2 menunjukkan bahwa 23 orang dari 24 pekerja K3L telah bertatus kawin. Dari tabel tersebut juga diketahui hanya 4,16\% K3L yang berstatus Janda. Adapun faktor penarik para 


\begin{tabular}{|c|c|c|c|c|}
\hline $\begin{array}{c}\text { Focus: } \\
\text { Jurnal Pekerjaan Sosial }\end{array}$ & ISSN: 2620-3367 & Vol. 1 No: 3 & Hal: 220 - 233 & Desember 2018 \\
\hline
\end{tabular}

pekerja K3L untuk bekerja di Unpad berdasarkan hasi wawancara sebesar 8,33 \% memilih alasan bahwa gaji yang ditawarkan lebih besar dari pekerjaan sebelumnya. Faktor kenyamanan tempat bekerja di Unpad yang menjadi salah satu opsi dengan hasil sebesar 8,33\%. Selain itu ada pula K3L yang akhirnya pindah bekerja karena ajakan teman, ukuran ini berkisar 16,66 \%. Namun nyatanya, alasan terbesar para K3L pindah bekerja ke Unpad adalah karena faktor-faktor lain selain yang telah disebutkan diatas. Hasil ini sebesar $66,66 \%$ atau sebanyak 16 orang dari 24 K3L yang diwawancara.

Tabel 2. Persentase Status Perkawinan K3L Zona 3

Berdasarkan hasil wawancara tersebut maka peran ganda pekerja K3L serta motivasi mereka bekerja memiliki keterkaitan. Berdasarkan penelitian Hernamawarni (2009), menyebutkan ada beberapa faktor yang menyebabkan wanita masuk ke dalam dunia kerja. Pada keluarga konvensional, suami memiliki tanggungjawab untuk mencari nafkah sedangkan istri bertugas untuk mengurus rumah tangga. Seiring berkembangnya waktu terjadi dualisme karir yaitu timbulnya peluang kesempatan bagi wanita bersuami untuk bekerja. Namun nilai-nilai tradisional seorang wanita yaitu 3M : masak, macak, manak

( memasak , bersolek, melahirkan anak ) disatu sisi dapat menjadi tekanan sosial ${ }^{1}$.

Ada beberapa faktor yang dimaksud antara lain untuk meningkatkan kualitas hidup, membayar utang, mengurangi ketergantungan terhadap suami dan meningkatkan status sosial. Keterlibatan wanita tersebut tidak lepas dari tekanan ekonomi

\footnotetext{
${ }^{1}$ Mayling OG, dkk.Perempuan Indonesia Dulu dan Kini,(Jakarta;Gramedia Pustaka Utama,1996),hal.218
}

keluarga yang semakin tak terjangkau, suami tidak bekerja, serta menambah pendapatan suami. Rata-rata wanita yang bekerja sebagai buruh merupakan golongan ekonomi menengah kebawah serta tingkat pendidikan yang rendah.

Dengan menambahkan teori Hierarki Kebutuhan oleh Abraham $\mathrm{H}$. Maslow serta dengan berdasarkan latar belakang yang telah dipaparkan, penelitian ini dimaksudkan untuk menganalisis keterkaitan peran ganda angkatan kerja wanita K3L Universitas Padjajaran serta implementasinya menurut teori kebutuhan Maslow.

\begin{tabular}{|l|l|l|l|}
\hline No & Status Perkawinan & $\mathrm{f}$ & $\%$ \\
\hline 1 & Belum Kawin & 0 & $0 \%$ \\
\hline 2 & Kawin & 23 & $95,83 \%$ \\
\hline 3 & Janda/ Duda & 1 & $4,16 \%$ \\
\hline
\end{tabular}

\section{METODE}

Penelitian ini merupakan jenis penelitian deskriptif yaitu jenis penelitian yang bertujuan menyajikan fenomena mengenai situasi sosial atau mengeksplorasi dan mengklarifikasinya dengan mendeskripsikan sejumlah variable berkenaan dengan unit yang diteliti. Objek dari penelitian ini adalah para pekerja Kebersihan, Keindahan, Kenyamanan Lingkungan (K3L) pada Zona 3 di Universitas Padjajaran oleh Mahasiswa IImu Kesejahteraan Sosial Angkatan 2017.

Metode Pendekatan penelitian adalah kualitatif dengan teknik pengumpulan data wawancara terstruktur kepada 24 orang responden, studi dokumentasi, observasi, dan kepustakaan.

\section{HASI L DAN PEMBAHASAN}




\begin{tabular}{|c|c|c|c|c|}
\hline $\begin{array}{c}\text { Focus: } \\
\text { Jurnal Pekerjaan Sosial }\end{array}$ & ISSN: 2620-3367 & Vol. 1 No: 3 & Hal: $220-233$ & Desember 2018 \\
\hline
\end{tabular}

\section{Peran Perempuan dan Paradigma Pembagian Kerja dalam Keluarga}

Setiap manusia tentunya memiliki peran. Semakin bertambahnya usia semakin banyak pula peran yang dimiliki , tidak terkecuali perempuan maupun laki-laki. Namun biasanya peran seorang perempuan lebih banyak dibandingkan dengan laki-laki. Fenomena seorang perempuan memiliki dua peran atau lebih ini dikenal juga dengan istilah "peran ganda wanita" yang juga dirasakan oleh pekerja K3L Universitas Padjajaran. Sebelum membahas lebih lanjut mengenai peran ganda wanita pekerja K3L , ada baiknya memahami terlebih dahulu apa itu peran.

Secara terminologi peran dapat didefinisikan sebagai pemain sandiwara (film), tukang lawak pada permainan makyong, perangkat tingkah yang diharapkan dimiliki oleh orang yang berkedudukan di masyarakat. Soerjono Soekanto ( 2002:243) mendefinisikan peran sebagai aspek dinamis dari kedudukan ( status), apabila seseorang melaksanakan hak dan kewajibannya sesuai dengan kedudukannya, maka ia menjalankan suatu peranan. Status tersebut diperoleh seseorang apabila telah melaksanakan hak dan kewajiban yang dimiliki seseorang sesuai dengan kedudukannya. Dengan kata lain ia telah menjalankan suatu fungsi dari perannya yang pada akhirnya memperoleh sebuah kedudukan ( status ).

Berdasarkan pemaparan diatas maka dapat disimpulkan bahwa peran merupakan aspek dinamis dari status yang dimiliki seseorang yang didalamnya mencakup fungsi atau tingkahlaku yang diharapkan pada individu sesuai hak dan kewajibannya.
Hubies ( dalam Alghaasyiyah:2014) menyatakan pendapatnya tentang pembagian peran wanita terbagi kedalam beberapa perspektif dalam posisinya sebagai manager rumah tangga, partisipan pembangunan, dan pekerja pencari nafkah kedalam tiga, antara lain: (1) peran tradisional, (2) peran transisi, dan (3) peran kontemporer.

Peran tradisional merupakan peran dasar wanita yang sudah diturunkan secara turun-temurun. Wanita harus dapat mengerjakan semua hal terkait dengan pekerjaan rumah, mulai dari membersihkan rumah, memasak, mencuci , hingga mengasuh anak. Aktivitas tersebut tentunya tidak dapat diukur dengan nilai materi atau uang. Disini peran wanita sebagai figure ibu sangat menenentukan keberlangsungan urusan rumah tangga serta perkembangan pribadi anak. Peran transisi pada wanita terjadi apabila ia juga memiliki peran bekerja untuk mencari nafkah. Sedangkan , peran kontemporer adalah peran dimana seorang wanita hanya memiliki peran di luar rumah tangga atau sebagai wanita karier.

Disamping itu , Perkumpulan Keluarga Berenana Indonesia ( PKBI ) mengklasifikasikan pembedaan peran antara laki-laki dan perempuan berdasarkan gender menjadi 4 , yaitu : Pertama, pembedaan peran dalam hal pekerjaan. Contohnya adalah perempuan dianggap memiliki pekerjaan reproduktif sedangkan laki-laki pekerja produktif. Kerja produktif dalam hal ini merupakan pekerjaan yang menghasilkan uang sedangkan reporduktif biasanya tidak menghasilkan uang seperti mengurusi pekerjaan rumah tangga dan melahirkan. Kedua, pembedaan wilayah kerja. Seperti yang telah dijelaskan sebelumnya, laki-laki diwilayah public ( luar rumah ) dan perempuan 


\begin{tabular}{|c|c|c|c|c|}
\hline $\begin{array}{c}\text { Focus: } \\
\text { Jurnal Pekerjaan Sosial }\end{array}$ & ISSN: 2620-3367 & Vol. 1 No: 3 & Hal: $220-233$ & Desember 2018 \\
\hline
\end{tabular}

domestic ( di dalam rumah atau pribadi ). Ketiga , pembedaan status. Seringkali laki-laki disini berperan sebagai subjek atau "si pemeran utama" sedangkan perempuan dianggap sebagai pemeran pelengkap atau membantu laki-laki. Keempat, pembedaan sifat. Seringkali perempuan identikdengan sifat feminim seperti lemah lembut, halus, sopan, emosional,"cantik",dll. Sedangkan laki-laki memiliki sifat maskulin yang kental seperti gagah, berotot, aktif, berani, kuat, rasional,dll.

Berdasarkan beberapa pengertian diatas maka dapat ditarik kesimpulan bahwa wanita memiliki beragam peran yang menjadi tata perilaku atau fungsinya sebagai seorang wanita baik seara kodratinya sebagai perempuan maupun secara sosial.

\section{Gender dan Perempuan Bekerja}

Analisis peran ganda wanita tidak lepas dari konsep gender dan seks ( jenis kelamin ). Agar memahami konsep tersebut maka pemaknaan kata gender dan seks ( jenis kelamin) harus dibedakan. Jenis kelamin mengacu kepada pembedaan jenis kelamin manusia secara biologis, yaitu laki-laki dan wanita. Secara biologis, pemaknaan jenis kelamin lebih mengacu kepada alat-alat reprodukinya yang melekat pada manusia sejah lahir. Dari sini dipahami bahwa ketentuan biologis secara kodratnya tidak dapat berubah sebagai ketentuan dari Tuhan.

Sementara itu, pengertian konsep gender lebih mengacu kepada sifatnya. Menurut Cixous dalam Tong ( 2004:41), gender merupakan : perbedaan yang tampak antara laki-laki dan wanita yang dilihat dari segi nilai dan tingkah laku. Disamping itu, Mansur Fakih dalam Analisis Gender dan Transofmasi sosial ( 2008:8) mendefinisikan gender sebagai sifat yang melekat pada kaum lakilaki maupun wanita yang dikonstruksi secara sosial maupun kultural. Sedangkan menurut Women's Studies EncycloPedia , gender digambarkan sebagai suatu konsep kulturan, berupaya membuat perbedaan dalam hal peran, perilaku, mentalis , dan karakteristik emosional antara laki-laki dan perempuan dalam masyarakat ( Women's Studies EncycloPedia dalam Sutinah:316)Sehingga dapat disimpulkan bahwa konsep gender merupakan perbedaan antara wanita dan laki-laki secara kultural maupun sosial.

Mansur Faqih (1996:8) mengartikan wanita dalam istilah gender sebagai manusia yang lemah lembut,anggun,keibuan,emosional, dan lain sebagainya. Pada kodratnya wanita memang sudah di gariskan untuk menjadi seorang istri dan ibu. Keterkaitannya dengan konsep gender, sifat wanita yang sering di kenakan adalah makhluk yang emosional, pasif, lemah, dekoratif, tidak asertif , tidak kompeten kecuali untuk tugas rumah tangga.

Peran ganda wanita dapat diartikan sebagai kepemilikan dua peran atau lebih yang di jalankan wanita dalam waktu yang bersamaan. Dalam konteks ini peran ganda yang dimaksud adalah peran wanita sebagai istri , ibu dan karir atau bekerja di luar rumah. Karir dapat diartikan sebagai cita-cita, ambisi, dan tujuan hidup seseorang dalam jangka panjang di dalam menekuni suatu bidang. Sedangkan, pekerjaan adalah kegiatan untuk mengganti waktu, kemampuan , dan tenaga kerja seseorang dengan uang. Walaupun pada kenyataannya hampir setiap wanita memiliki peran ganda yang sama baik itu menjadi seorang ibu yang bekerja ataupun berkarir namun hal pembeda dari satu dengan yang lain 


\begin{tabular}{|c|c|c|c|c|}
\hline $\begin{array}{c}\text { Focus: } \\
\text { Jurnal Pekerjaan Sosial }\end{array}$ & ISSN: 2620-3367 & Vol. 1 No: 3 & Hal: $220-233$ & Desember 2018 \\
\hline
\end{tabular}

adalah tujuan atau motivasinya. Pemilihan kata karir dan bekerja bagi seorang wanita dapat dilihat dari kelas sosialnya. Biasanya wanita yang berada pada kelas sosial atas dapat dikatakan berkarir. Hal ini tidak dapat disamaratakan dengan wanita yang berasal dari kelas sosial menengah maupun bawah. Seperti halnya wanita bekerja dengan profesi professional akan berbeda motivasinya dengan petani atau buruh wanita.

Siagian (1984) berpendapat bahwa peran wanita desa dapat dibagi dalam dua bagian (1) sebagai istri atau ibu rumah tangga, dimana mereka melakukan pekerjaan rumah tangga yang tidak menghasilkan pendapatan secara langsung tetapi tidak memungkinkan anggota keluarga lain melakukan pekerjaan mencari nafkah, (2) membantu untuk mencari nafkah dalam kehidupan keluarga sehari-hari dimana biasanya wanita mendapingi suami bekerja untuk mencari nafkah. Sedangkan Munandar (1985) menyebutkan pendaptanya bahwa peranan wanita bukan saja hanya bekerja di dalam rumah tangganya, yaitu melayani, seperti mendidik, merawat, mengatur untuk dinikmati oleh orang lain atau minikmati bersama-sama dengan orang lain. Tetapi juga bekerja, yaitu melakukan kegiatan yang memberikan penghasilan untuk kebutuhan keluarga.

Dalam pengertian ekonomi wanita yang bekerja dikaitkan dengan tingkat angkatan kerja. Fenomena wanita yang bekerja kerap kali disertai karena alasan ekonomi keluarga maupun membantu mencukupi kebutuhan keluarga. Dari sini kita ketahui bahwa peran wanita bekerja membarikan kontribusi besar pada peningkatan kesejahteraan keluarga.
Fergus (dikutip dalam Hidayat, 2006) menyebutkan bahwa desakan ekonomi khususnya bagi ibu yang berpendidikan SD ke bawah menjadi faktor yang paling mempengaruhinya untuk masuk ke pasar kerja. Sedangkan dalam kasus lain, bagi wanita kepala keluarga, bekerja menjadi kewajiban untuk memperoleh penghasilan dan mencukupkan kebutuhan keluargaKeterlibatan wanita dalam pasar tenaga kerja ini dipengaruhi oleh faktor internal dan faktor eksternal. Faktor internal atau faktor pendorong wanita untuk bekerja antara lain karena kesulitan dalam perkonomian keluarga. Sedangkan faktor eksternal atau faktor penarik keterlibatan wanita dalam pasar kerja berasal dari adanya kesempatan kerja yang ditawarkan oleh kapitalis ( Sudarwati:2003).

\section{Teori Hirarki Kebutuhan}

Kerja merupakan salah satu unsur hakikat manusia , sehingga manusia dapat disebut sebagai makhluk bekerja. Intensitas kerja manusia memiliki sifat khas yang berbeda dari kerja binatang maupun kerja mesin. Binatang bekerja dengan menuruti nalurinya sedangkan mesin bekerja tanpa kesadaran. Perbedaannya, kerja manusia tidak hanya sekedar didasari nalurinya melainkan merupakan gabungan dari daya rohani dan badani yang ia laksanakan dengan sadar. Namun pada dasarnya kegiatan kerja dilakukan untuk memenuhi sebuah kebutuhan.

Ashar ( 2001 ) mendefinisikan motivasi kerja sebagai suatu proses dimana kebutuhankebutuhan mendorong seseorang untuk melakukan serangkaian kegiatan yang mengarah ke tercapainya tujuan tertentu. Sedangkan Robbins dan Judge ( 2007 ) berpendapat bahwa motivasi kerja adalah proses yang menjelaskan intensitas, 


\begin{tabular}{|c|c|c|c|c|}
\hline $\begin{array}{c}\text { Focus: } \\
\text { Jurnal Pekerjaan Sosial }\end{array}$ & ISSN: 2620-3367 & Vol. 1 No: 3 & Hal: $220-233$ & Desember 2018 \\
\hline
\end{tabular}

arah, dan ketekunan usaha untuk mencapai suatu tujuan dalam organisasi.

Bekerja, motivasi serta kebutuhan merupakan 3 hal yang tidak dapat dipisahkan dalam pembahasannya. Walaupun sejatinya hakikat manusia adalah bekerja untuk memenuhi kebutuhannya, namun motivasi atau tujuan seseorang bekerja sifatnya sangat beragam. Menurut Teori Hirarki Kebutuhan atau Teori Motivasi, Abraham Maslow (1943:1970) menyebutkan bahwa kebutuhan pokok manusia tersusun dalam bentuk hirarki atau berjenjang. Maslow menggambarkan tingkatan kebutuhan terebut kedalam 5 kebutuhan dasar yang di paparkan kedalam piramida tingaktan dengan dimulai dari (1) kebutuhan fisiologis , (2) kebutuhan keamanan( safety), (3) kebutuhan dimiliki dan cinta ( belonging and love ), (4) kebutuhan harga diri ( self esteem ), (5) kebutuhan aktualisasi diri. Kebutuhan tersebut tersusun dari yang sifatnya pemenuhan biologis hingga psikologis kompleks.

Kebutuhan fisiologis merupakan kebutuhan paling mendasar dari piramida Maslow. Kebutuhan ini bersifat neostatik atau primer seperti kebutuhan makan, minum, gula,istirahat, dll. Selain itu, kebutuhan fisiologis sangat kuat perannya karena kebutuhan ini sifatnya jangka pendek ,apabila dalam keadaan absolut seperti kelaparan ,maka seluruh kebutuhan lain akan ditinggalkan demi terpenuhinya kebutuhan ini. Karenanya kebutuhan ini merupakan kebutuhan yang paling kuat dan mendesak pemenuhannya. Maka dapat disimpulkan apabila pada diri manusia sangat kekurangan dalam pemenuhan segala-galanya, besar kemungkinan motivasi terbesar ialah kebutuhan fisiologis.
Selanjutnya, pemenuhan kebutuhan rasa aman (safety needs ) merupakan kebutuhan pada hierarki kedua pada piramida Maslow. Manusia memerlukan perasaan aman atau kepastian dalam pemenuhan upaya keberlangsungan hidupnya dalam jangka pendek maupun panjang. Kebutuhan ini mencakup perlindungan diri terhadap bahaya , cedera, ancaman, kecelakaan, kerugian atau kehilangan. Didalam organisasi kebutuhan rasa aman terlihat pada keinginan akan kepastian pekerjaan, serikat kerja, imbalan-imbalan tambahan, asuransi , tabungan , dan kemungkinan pensiun.

Setelah kebutuhan fisiologis dan rasa aman terpenuhi , maka fokus seseorang akan berlain pada kebutuhan dimiliki dan cinta atau kebutuhan untuk diterima. Sebagai makhluk sosial , manusia merasa senang apabila mereka dicintai , diterima begitupun sebaliknya. Terdapat dua jenis cinta yakni Deficiency atau D-Love dan Being atau BLove. D-Love didefinisikan sebagai kebutuhan cinta karena kekurangan, cinta seseorang akan seusuatu yang tidak dimillikinya seperti harga diri, seks, atau seseorang yang membuat dirinya menjadi tidak sendirian ( hubungan pacaran, pernikahan ). Sedangkan, B-Love didasarkan pada penilaian terhadap orang lain apa adanya tanpa memanfaatkan orang tersebut.

Kebutuhan pada hierarki keempat adalah kebutuhan untuk dihargai (Self Esteem Needs). Self Esteem dibedakan menjadi dua jenis : (1) self respect yaitu adalah pemuasan menghargai diri sendiri dan (2) respect from other yaitu mencakup kebutuhan prestise, pengekuan dari oranglain , apresiasi, dan kehormatan. Pada kebutuhan dasar terakhir adalah aktualisasi diri. Pada akhirnya setelah semua kebutuhan dasar terpenuhi, 


\begin{tabular}{|c|c|c|c|c|}
\hline $\begin{array}{c}\text { Focus: } \\
\text { Jurnal Pekerjaan Sosial }\end{array}$ & ISSN: 2620-3367 & Vol. 1 No: 3 & Hal: $220-233$ & Desember 2018 \\
\hline
\end{tabular}

kebutuhan aktualisasi diri diraih untuk memaksimalkan seluruh kemampuan dan potensinya. Kebutuhan inidividu akan penghargaan ini disebut juga sebagaikebutuhan"ego".

Terakhir, kebutuhan paling atas dalam piramida Maslow adalah kebutuhan aktualisasi diri ( Self Actualization ). Karena menempati tingkata paling atas pada piramida Maslow, maka disebut juga sebagai kebutuhan pemenuhan diri. Tujuan dari pemenuhan kebutuhan ini adalah memaksimalkan kemampuan diri dan menjadi manusia yang lebih baik lagi.

Tabel 3. Teori Kebutuhan Abraham H. Maslow oleh Richard L.Daft

\begin{tabular}{|l|l|l|}
\hline $\begin{array}{l}\text { Pemenuhan } \\
\text { di luar } \\
\text { Pekerjaan }\end{array}$ & $\begin{array}{l}\text { Hirarki } \\
\text { Kebutuhan } \\
\text { Manusia }\end{array}$ & $\begin{array}{l}\text { Pemenuhan } \\
\text { dalam } \\
\text { Pekerjaan }\end{array}$ \\
\hline $\begin{array}{l}\text { Pendidikan, } \\
\text { Religi, Hobi , } \\
\text { Pertumbuhan } \\
\text { Pribadi }\end{array}$ & $\begin{array}{l}\text { Kebutuhan } \\
\text { Aktualisasi }\end{array}$ & $\begin{array}{l}\text { Kesempatan } \\
\text { untuk } \\
\text { pelatihan, } \\
\text { kemajuan, } \\
\text { pertumbuhan } \\
\text { dan kreatifitas }\end{array}$ \\
\hline $\begin{array}{l}\text { Persetujuan } \\
\text { keluarga, } \\
\text { teman, } \\
\text { komunitas }\end{array}$ & $\begin{array}{l}\text { Kebutuhan } \\
\text { dihargai }\end{array}$ & $\begin{array}{l}\text { Pengakuan, } \\
\text { status tinggi, } \\
\text { meningkatkan } \\
\text { tanggung } \\
\text { jawab }\end{array}$ \\
\hline $\begin{array}{l}\text { Keluarga, } \\
\text { teman, grup } \\
\text { komuniats }\end{array}$ & $\begin{array}{l}\text { Kebutuhan } \\
\text { diterima }\end{array}$ & $\begin{array}{l}\text { Kelompok } \\
\text { kerja, rekan } \\
\text { kerja, } \\
\text { supervisor }\end{array}$ \\
\hline $\begin{array}{l}\text { Bebas dari } \\
\text { perang, } \\
\text { polusi } \\
\text { kekerasan }\end{array}$ & $\begin{array}{l}\text { Kebutuhan } \\
\text { akan rasa } \\
\text { aman }\end{array}$ & $\begin{array}{l}\text { Kerja yang } \\
\text { aman, } \\
\text { tunjangan }\end{array}$ \\
\hline
\end{tabular}

\begin{tabular}{|l|l|l|}
\hline & & $\begin{array}{l}\text { kerja, } \\
\text { jaminan }\end{array}$ \\
\hline $\begin{array}{l}\text { Makanan, air, } \\
\text { oksigen }\end{array}$ & $\begin{array}{l}\text { Kebutuhan } \\
\text { fisiologis }\end{array}$ & $\begin{array}{l}\text { udara, gaji } \\
\text { pokok }\end{array}$ \\
\hline
\end{tabular}

\section{Peran Ganda Wanita Pekerja K3L}

Mahasiswa IImu Kesejahteraan Sosial Universitas Padjajaran telah melakukan wawancara terukur dengan menggunakan kuesioner kepada beberapa petugas K3L yang tersebar di seluruh wilayan Universitas Padjajaran. Identitas pekerja K3L di Universitas Padajajaran dibedakan berdasarkan beberapa zona wilayah bekerja K3L. Pembahasan artikel mengambil data pekerja K3L dari zona 3 yaitu pada lingkup wilayah Fakultas Kedokteran Universitas Padjajaran dan sekitarnya. Tugas para pekerja K3L mencakup kegiatan menyapu area di sekitar fakultas dan jalanan, membersihkan dan merawat pekarangan dan serta mencabuti rumput. Data yang diperoleh juga merupakan data primer berdasarkan hasil wawancara dengan responden pada Kantor Pengelolaan Lingkungan Direktorat Sarana dan Prasarana Universitas Padjajaran, Duduh Syahroni. Duduh menyatakan bahwa Petugas K3L yang merupaakan singkatan dari Kebersihan, Keindahan, dan Kenyamanan Lingkungan merupakan salah satu bentuk aksi sosial Universitas Padjajaran untuk memberdayakan warga J atinangor.

Untuk bekerja menjadi petugas K3L sendiri tidak ditentukan syarat khusus seperti pendidikan minimal ataupun syarat lainnya, hanya saja para calon K3L harus mengajukan surat lamaran kepada Kantor Pengelolaan Lingkungan Direktorat Sarana dan Prasarana Universitas Padjajaran untuk tindakan lanjut. 


\begin{tabular}{|c|c|c|c|c|}
\hline $\begin{array}{c}\text { Focus: } \\
\text { Jurnal Pekerjaan Sosial }\end{array}$ & ISSN: 2620-3367 & Vol. 1 No: 3 & Hal: $220-233$ & Desember 2018 \\
\hline
\end{tabular}

Berdasarkan data primer yang diperoleh melalui wawancara yang dilakukan kepada $24 \mathrm{~K} 3 \mathrm{~L}$, diketahui bahwa mayoritas pekerja K3L pada zona 3 Universitas Padajajaran berjenis kelamin perempuan dan berstatus sudah menikah. Sebanyak $75 \%$ responden K3L berjenis kelamin perempuan dan 95,83\% diantaranya berstatus sudah menikah.

Selanjutnya, diketahui pula bahwa persentase terbesar rata-rata usia pekerja K3L pada Zona 3 adalah diatas 35 tahun dengan persentasenya $83,87 \%$.

\begin{tabular}{|l|l|l|l|}
\hline No & \multicolumn{1}{|c|}{ umur } & \multicolumn{1}{c|}{$f$} & \multicolumn{1}{c|}{$\%$} \\
\hline 1 & $14-19$ & 0 & $0 \%$ \\
\hline 2 & $20-24$ & 1 & $3,2 \%$ \\
\hline 3 & $25-29$ & 2 & $6,45 \%$ \\
\hline 4 & $30-34$ & 2 & $6,45 \%$ \\
\hline 5 & $>35$ & 26 & $83,87 \%$ \\
\hline
\end{tabular}

Tabel. 4 Persentase umur pekerja K3L

Dari sini diketahui bahwa mayoritas pekerja K3L dapat digolongkan sebagai tenaga kerja produktif. Adapun definisi tenaga kerja menurut UU No. 13 tahun 2003 Bab 1 pasal 1 ayat 2 bahwa tenaga kerja adalah setiap orang yang mampu melakkukan pekerjaan guna menghsilkan barang atau jasa baik untuk memenuhi kebutuhan sendiri maupun untuk masyarakat. Batasan kerja di Indonesia sendiri ditentukan dari usia 15 tahun hingga 64 tahun.Dengan demikian, dapat ditarik kesimpulan bahwa pekerja K3L Universitas Padjajaran zona 3 mayoritas berjenis kelamin perempuan pada usia rata-rata diatas 35 tahun dengan status sudah menikah.

Pengambilan peran oleh para pekerja K3L wanita sebagai seorang ibu yang bekerja tentunya tidak mudah. Seperti yang dikatakan oleh Hubies (dalam Alghaasyiyah :2014) bahwa pembagian peran wanita berdasarkan perspektif dalam posisinya dapat dilihat sebagai manager rumah tangga, partisipan pembangunan, serta pencari nafkah. Pada bagian sebelumnya telah dibahas konsep mengenai peran wanita secara umum. Sedangkan secara khusus konsep peran pekerja wanita K3L yang pada umumnya merupakan penduduk Jatinangor dapat diterapkan melalui pembagian peran wanita desa oleh Siagian.

Siagian (1984) berpendapat bahwa peran wanita desa dapat dibagi dalam dua bagian (1) sebagai istri atau ibu rumah tangga, dimana mereka melakukan pekerjaan rumah tangga yang tidak menghasilkan pendapatan secara langsung tetapi tidak memungkinkan anggota keluarga lain melakukan pekerjaan mencari nafkah, (2) membantu untuk mencari nafkah dalam kehidupan keluarga sehari-hari dimana biasanya wanita mendapingi suami bekerja untuk mencari nafkah.

Dalam hukum juga dijelaskan pula mengenai pembagian kerja antara perempuan dan laki-laki dalam rumah tangga dalam pasal 34 ayat 2 UU Perkawinan yang berisi bahwa istri wajib mengurus urusan rumah tangga sebaik-baiknya. Bergesernya pekerjaan wanita dari sektor domestic ke pbulik ini tlah melekatkan peran ganda pada diri wanita itu sendiri ( Sulsilawati 1998 ).

Dalam pengertian ekonomi wanita yang bekerja dikaitkan dengan tingkat angkatan kerja. Fenomena wanita yang bekerja kerap kali disertai karena alasan ekonomi keluarga maupun membantu mencukupi kebutuhan keluarga. Dari sini kita ketahui bahwa peran wanita bekerja membarikan kontribusi besar pada peningkatan kesejahteraan keluarga. Fergus ( dikutip dalam Hidayat, 2006 ) menyebutkan bahwa desakan ekonomi khususnya bagi ibu yan berpendidikan SD 


\begin{tabular}{|c|c|c|c|c|}
\hline $\begin{array}{c}\text { Focus: } \\
\text { Jurnal Pekerjaan Sosial }\end{array}$ & ISSN: 2620-3367 & Vol. 1 No: 3 & Hal: $220-233$ & Desember 2018 \\
\hline
\end{tabular}

ke bawah menjadi faktor yang paling mempengaruhinya untuk masuk ke pasar kerja. Sedangkan dalam kasus lain, bagi wanita kepala keluarga, bekerja menjadi kewajiban untuk memperoleh penghasilan dan mencukupkan kebutuhan keluarga.Keterlibatan wanita dalam pasar tenaga kerja ini dipengaruhi oleh faktor internal dan faktor eksternal. Faktor internal atau faktor pendorong wanita untuk bekerja antara lain karena kesulitan dalam perkonomian keluarga. Sedangkan faktor eksternal atau faktor penarik keterlibatan wanita dalam pasar kerja berasal dari adanya kesempatan kerja yang ditawarkan oleh kapitalis ( Sudarwati:2003).

Dengan demikian, wanita pekerja K3L Universitas Padjajaran saat ini telah menyandang dua peran. Peran pertama pekerja K3L tersebut adalah sebagai seorang istri dan ibu yang memiliki tugas untuk mengatur persoalan pekerjaan rumah tangga yang secara ekonomi tidak menghasilkan pendapatan. Sedangkan, peran kedua pekerja K3L ini adalah sebagai pendukung suami untuk mencari penghasilan dalam pemenuhan kebutuhan keluarga sehari-hari. Masalah yang dihadapi oleh pekerja wanita K3L Universitas Padjajaran yang sudah menikah tersebut adalah tuntutannya untuk berperan sebagai ibu rumah tangga sehingga konsekuensinya harus berperan ganda ( double burden).

\section{I mplementasi Teori Kebutuhan Maslow pada Pekerja K3L}

Setiap manusia haruslah bekerja. Bekerja merupakan salah satu kewajiban yang harus dijalankan manusia dengan tujuan untuk memenuhi kebutuhan hidupnya. Tidak hanya untuk memenuhi kebutuhan hidupnya, namun seseorang yang bekerja juga bertujuan untuk mencapai taraf hidup yang lebih baik. Dalam konteks K3L khususnya wanita pekerja K3L kehadiran Teori Maslow tentang kebutuhan dan motivasi dapat menjadi rujukan ilmiah untuk mengetahui sejauh mana tingkatan motivasi K3L dalam bekerja. Untuk mempermudah analisa tersebut, maka bagian ini akan ditinjau dari data riwayat pekerjaan $\mathrm{K} 3 \mathrm{~L}$.

Seperti yang telah dijelaskan sebelumnya, bahwa K3L merupakan salah satu bentuk pengabdian sosial berupa penyediaan lapangan pekerjaan oleh Universitas Padjajaran kepada warga sekitar Jatinangor. Masyarakat yang mendaftar menjadi petugas K3L pun beragam, mulai dari yang belum memiliki pekerjaan ( pengangguran ) atau sudah pernah bekerja ditempat lain sebelumnya. Dari data primer yang diperoleh, diketahui bahwa sebanyak $62,5 \% \mathrm{~K} 3 \mathrm{~L}$ sebelumnya pernah bekerja di tempat lain, sedangkan $37,5 \%$ belum pernah bekerja sebelumnya.

Angka tersebut berasosiasi dengan data yang menyatakan 95,83\% K3L pada zona 3 berjenis kelamin perempuan dan $83,87 \%$ diantaranya berusia diatas 35 tahun. Adapun alasan para K3L meninggalkan pekerjaan lamanya disebabkan karena gaji yang diperoleh dianggap terlalu kecil. Alasan berikutnya disebabkan oleh masa kontrak pekerjaan lama yang sudah habis atau tidak dapat diperpanjang sehingga menyebabkan pemutusan pekerjaan sepihak. Namun, ternyata mayoritas pekerja $\mathrm{k} 3 \mathrm{l}$ meninggalkan pekerjaan lamanya dengan alasan lain diluar opsi yang tersedia pada wawancara.

Faktor lain-lain tersebut mencakup tentang masalah pemenuhan kebutuhan sehari-hari. Ambiguitas pekerjaan menjadi buruh tidak tetap di 


\begin{tabular}{|c|c|c|c|c|}
\hline $\begin{array}{c}\text { Focus: } \\
\text { Jurnal Pekerjaan Sosial }\end{array}$ & ISSN: 2620-3367 & Vol. 1 No: 3 & Hal: $220-233$ & Desember 2018 \\
\hline
\end{tabular}

pekerjaan sebelumnya membuat K3L senantiasa mencari pekerjaan tetap yang dapat menopang pemenuhan kebutuhan hidup dan keluarganya. Kekhawatiran tersebut dipicu dari perolehan gaji yang tidak menentu. Alasan lain pemberhentian pekerjaan juga disebabkan karena saat itu sedang dalam keadaan mengandung. Sebelum menjadi K3L mayoritas dari mereka bekerja sebagai buruh pabrik, pegawai rumah makan, tukang kebun, dan tukang.

\begin{tabular}{|l|l|c|c|}
\hline No & \multicolumn{1}{|c|}{$\begin{array}{c}\text { Alasan } \\
\text { Meninggalkan } \\
\text { Pekerjaan Lama }\end{array}$} & $\mathrm{F}$ & $\%$ \\
\hline 1 & Gajinya Kecil & 2 & $8,33 \%$ \\
\hline 2 & Suasana Tak Enak & 0 & $0 \%$ \\
\hline 3 & $\begin{array}{l}\text { Kontrak Tak Dapat } \\
\text { Diperpanjang }\end{array}$ & 3 & $12,5 \%$ \\
\hline 4 & Lain-Lain & 19 & $79,16 \%$ \\
\hline
\end{tabular}

Tabel.5 Persentase alasan meinggalkan pekerjaan lam

Disamping faktor pendorong diatas ada pula faktor penarik masyarkat Jatinangor untuk menjadi pekerja K3L. Hasil data primer yang telah dioleh menunjukkan bahwa sebesar $8,33 \%$ memutuskan untuk melamar dan bekerja menjadi K3L dengan alasan gaji yang diperoleh lebih besar serta suasana lingkungan bekerja yang lebih nyaman dari pekrjaan sebelumnya. Pada kolom lain-lain menunjukkan persentase terbesar pekerja untuk menjadi petugas K3L. Alasan lain-lain tersebut mencakup berbagai faktor, mulai dari ekonomi hingga keinginan pribadi. Walaupun gaji yang diperoleh sebagai K3L tidak jauh berbeda dari pekerjaan sebelumnya, namun hal yang membedakan tersebut adalah pemberian gaji yang bersifat tetap. Poin ini merupakan salah satu contoh dari kebutuhan merasa aman dari segi finansial K3I. Lainnya berpendapat untuk mendapatkan pengalaman baru, keinginan sendiri, ketidak pastian pekerjaan, gajinya tetap walaupun kecil, mencari kesibukan dengan daerah/ tempat yang tidak jauh dari rumah, diajak adik

\begin{tabular}{|c|c|c|c|}
\hline No & $\begin{array}{c}\text { Alasan Pindah } \\
\text { Bekerja di Unpad }\end{array}$ & $f$ & $\%$ \\
\hline 1 & $\begin{array}{l}\text { Gajinya Lebih } \\
\text { Besar }\end{array}$ & 2 & $8,33 \%$ \\
\hline 2 & Suasananya Enak & 2 & $8,33 \%$ \\
\hline 3 & Diajak Teman & 4 & $16,66 \%$ \\
\hline 4 & Lain-Lain & 16 & $66,66 \%$ \\
\hline
\end{tabular}

Tabel. 6 Persentase alasan pindah bekerja menjadi petugas $\mathrm{K} 3 \mathrm{~L}$

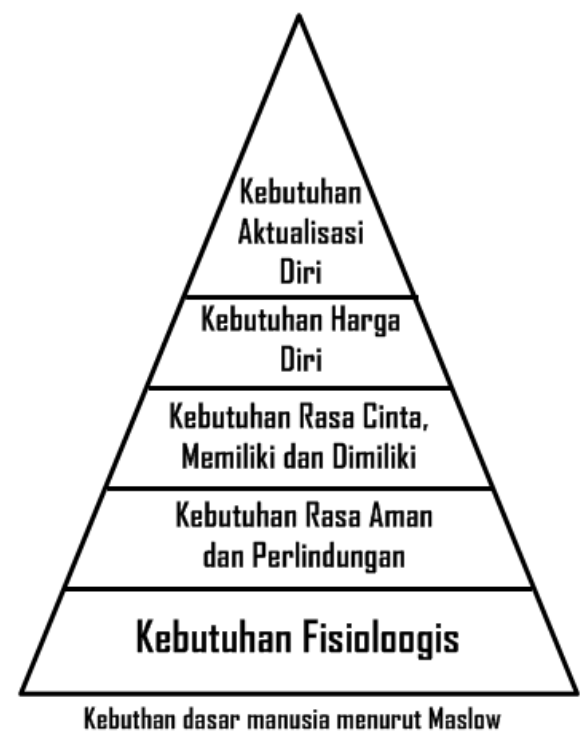

Gambar 1. Sumber : Stephen P.Robbins and Timothy A. Judge, Perilaku Organisasi, Jakarta, Salemba Empat (2008)

Teori Maslow menegaskan bahwa dalam pemenuhan kebutuhan manusia variasi tersebut dilihat secara hirarki atau berjenjang. Jadi orang akan termotivasi untuk naik ke tahap pemenuhan kebutuhan berikutnya apabila kebutuhan dasar (fisiologis) telah terpenuhi. Dari hasil wawancara 


\begin{tabular}{|c|c|c|c|c|}
\hline $\begin{array}{c}\text { Focus: } \\
\text { Jurnal Pekerjaan Sosial }\end{array}$ & ISSN: 2620-3367 & Vol. 1 No: 3 & Hal: $220-233$ & Desember 2018 \\
\hline
\end{tabular}

langsung dengan K3L diketahui bahwa alasan utama untuk bekerja adalah memenuhi kebutuhan hidupnya (primer). Gaji yang diberikan oleh Universitas Padjajaran kepada K3L sebesar Rp.750.000 rupiah per bulan yang akan di transfer ke rekening masing-masing petugas $\mathrm{K} 3 \mathrm{~L}$. Walaupun gaji yang diperoleh tidak berbeda jauh dari pekerjaan sebelumnya namun ada perasaan aman dalam hal penerimaan gaji. Di pekerjaan sebelumnya kerap kalli K3L dilanda kekhawatiran karena penghasilan yang tidak menentu. Manfaat penerimaan gaji dengan sistem transfer rekening yang diberlakukan Unpad telah memenuhi kebutuhan dasar pada hierarki kedua pada piramida Maslow. Dengan demikian dapat dikatakan motivasi K3L untuk bekerja telah sampai pada tingkatan kedua.

Walaupun motivasi dalam bekerja K3L dapat dikatakan berada pada tingkatan kedua pada hierarki Maslow, namun secara keseluruhan hierarki ini berhenti pada kebutuhan dasar ketiga , yaitu Belonging and love. Manusia sangat peka dengan kesendirian, ditolak lingkungan, kehilangan cinta,dll sehingga kebutuhan ini menjadi salah satu tujuan dominan yang penting untuk dimiliki sepanjang hidup.Sebanyak 95,83\% pekerja K3L pada zona 3 telah berstatus kawin atau menikah. Selain itu 8,33\% memutuskan pindah bekerja menjadi K3L karena faktor kenyamanan lingkungan bekerja. Beberapa dari K3L mengaku cukup senang dengan lingkungan sosial dari segi pertemanan antar sesama K3L Unpad.

Ada beberapa kendala yang menjadi alasan K3L belum bisa memasuki hierarki keempat (Esteem Needs) dan kelima (Metaneeds), salah satunya adalah dari kualitas sumber daya manusianya. Dari segi pendidikan 15 dari $24 \mathrm{~K} 3 \mathrm{~L}$ atau sebesar 62,5\% menempuh pendidikan akhirnya di Sekolah Dasar. Rendahnya tingkat pendidikan serta keterbatasan skill berpengaruh besar akan prospeks kerja individu. Kualitas tenaga kerja yang dihasilkanpun tidak dapat disamakan dengan individu dengan pendidikan yang lebih tinggi.

Dalam UU No. 13 tahun 2003 tentang tenaga kerja menjabarkan jenis-jenis tenaga kerja kedalam 3 , yaitu : (1) Tenaga kerja terdidik, yaitu tenaga kerja yang membutuhkan jenjang pendidikan tertentu seperti dokter, guru ,dsb (2) Tenaga kerja terlatih, yaitu tenaga kerja yang membutuhkan pelatihan dan pengalamam khusus seperti sopir, montir, dsb. (3) Tenaga kerja tidak terdidik dan tidak terlatih, merupakan tenaga kerja yang tidak membutuhkan pelatihan atau pendidikan khusus. Misalnya tukang sapu , tukang sampah, dsb. Dari hasil wawancara yang dilakukan kepada staff dan coordinator Kantor Pengelolaan Lingkungan Direktorat Sarana dan Prasarana Unpad disebutkan bahwa tidak ada persyaratan khusus sperti pendidikan maupun pelatihan bagi pekerja K3L untuk bekerja. Dengan kata lain, pekerja K3L Unpad dapat digolongkan kedalam tenaga kerja tidak terdidik dan tidak terlatih.

\section{Kesimpulan}

Sejatinya, seorang perempuan memiliki kodrat untuk mengurus tugas-tugas domestik seperti memasak, mengasuh, mendidik anak, serta melakukan berbagai pekerjaan rumah lainnya. Namun faktanya, saat ini perempuan dituntut untuk memiliki peran lebih. Hal ini yang pula dirasakan oleh wanita pekerja K3L. Disamping perannya sebagai seorang ibu dan istri, mereka harus bekerja untuk menopang kebutuhan 


\begin{tabular}{|c|c|c|c|c|}
\hline $\begin{array}{c}\text { Focus: } \\
\text { Jurnal Pekerjaan Sosial }\end{array}$ & ISSN: 2620-3367 & Vol. 1 No: 3 & Hal: $220-233$ & Desember 2018 \\
\hline
\end{tabular}

hidupnya. Dengan kata lain wanita pekerja K3L UNPAD memiliki peran transisi yaitu, peran yang terjadi apabila seorang wanita disamping mengurusi urusan rumah tangga juga bekerja untuk mencari nafkah.

Pemikiran Abraham Maslow dalam Teori Hierarki Kebutuhan juga telah memberi petunjuk yang komprehensif untuk mengkaji kebutuhan yang bisa memotivasi manusia dalam bekerja. Analisis data K3L dengan Teori Maslow membuktikan bahwa pemenuhan kebutuhan dasar ( fisiologis ) selalu menjadi pemenuhan yang bersifat urgent karena merupakan pemenuhan dalam jangka waktu pendek. Terbukti dari banyaknya petugas K3L yang mayoritas berjenis kelamin perempuan dengan usia diatas 35 tahun. Tuntutan ekonomi memaksa K3L untuk mencari tambahan nafkah bagi keluarga.

\section{Daftar Pustaka}

Aristya Rahmaryati M., B. W. (2017). Peran Ganda Buruh Perempuan Sektor Industri Dalam Keluarga. Jurnal Penelitian dan PKM, Vol. 4, No. 2: 129-389.

Aswiyati, I. (2016). Peran Wanita Dalam Menunjang Perekonomian Rumah Tangga Keluarga Petani Tradisioinal Untuk Penanggulangan Kemiskinan di Desa Kuwil Kecamatan Kalawat. Jurnal Holistik, No. 17 :1-18.

Darmawani. (2013). Peran Perempuan Dalam Meningkatkan Perekonomian Keluarga ( Studi Kasus di Gampong Punaga Pasie Kecamatan Meureubo Kabupaten Aceh Barat). Skripsi Universitas Teuku Umar Meulabobh.
Ermanovida, S. (2005). Memahami Pembagian Peran Gender Antara Laki-Laki dan Perempuan Dalam Keluarga. Empirika Fisip Unsri, Vol. 9,No. 1: 62-66.

Evaliani, D. R. (2014). STRATEGI PARTAI POLITIK DALAM PEMENANGAN CALON ANGGOTA LEGISLATIF PEREMPUAN PADA PEMI LI HAN UMUM LEGI SLATIF 2014(Studi pada Partai PKS, PDI-P dan Partai NasDem Kota Bandar Lampung). Skrisi I/mu Pemerintahan, 17-25.

Faqih, M. (1996). Analisis Gender dan Transformasi sosial. Yogyakarta.

gunadarma, W. (2009, November 16). WartaWarga Student Journalism. Retrieved Juni 8, 2018, from http://wartawarga.gunadarma.ac.id/2009 /11/motivasi-teori-hirarki-kebutuhanmaslow/

Iskandar. (2016). Implementasi Teori Hirarki Kebutuhan Abraham Maslow Terhadap Peningkatan Kinerja Pustakawan. Khizanah Al-Hikmah, Vol. 4, No .1 24-34.

Likty, C. P. (2016). Strategi Bertahan Hidup Perempuan Pemulung (Studi Kasus Terhadap Empat Pemulung Perempuan Kepala Keluarga yang Ada. Skripsi , 12-40.

PKBI. (n.d.). Pembagian Peran Berdasarkan Gender. Retrieved Juni 10, 2018, from PKBI ( Perkumpulan Keluarga Bererncana Indonesia ) Daerah Istimewa Yogyakarta: https://pkbi-diy.info/pembagian-peranberdasarkan-gender/

Rahmadita, I. (2013). Hubungan Antara Konflik Peran Ganda dan Dukungan Sosial Pasangan Dengan Motivasi Kerja Pada Karyawati di Rumah Sakit Abdul Rivai- 
Berau. elournal Psikologi, Vol. 1, No. 1: 56-68.

Ridwan, M. M. (2002). Perempuan Dalam Keluarga Sebagai Buruh Pabrik dan Ibu Rumah Tangga. Skripsi Institut Agama Islam Negri Sunan Ampel Surabaya.

Soekanto, S. (1993). Beberapa Teori Sosiologi Tentang Struktur Masyarakat. Jakarta: Citra Niaga Rajawali Pers.

Soerjono, S. (1999). Sosiologi Suatu Pengantar. J akarta: Media Utama.

Susilawati, D. P. (n.d.). Studi Faktor-Faktor Yang Memepengaruhi Wanita Bekerja di Kota Denpasar. PIRAMIDA , Jurnal Kependudukan dan Pengembangan Sumber Daya Manusia, Vol. 9, No. 1:2631. 